\title{
University
}

Bhattacharya, S. (2019) Writing famine, writing empire: food crisis and

anticolonial aesthetics in Liam O'Flaherty's Famine and Bhabani Bhattacharya's So Many Hungers! Irish University Review, 49(1), pp. 54-

73. (doi:10.3366/iur.2019.0380)

There may be differences between this version and the published version. You are advised to consult the publisher's version if you wish to cite from it.

http://eprints.gla.ac.uk/193192/

Deposited on: 04 October 2019

Enlighten - Research publications by members of the University of Glasgow http://eprints.gla.ac.uk 


\section{Writing Famine, Writing Empire: Food Crisis and Anticolonial Aesthetics in Liam O'Flaherty's Famine and Bhabani Bhattacharya's So Many Hungers!}

The eighteenth and nineteenth centuries witnessed a number of devastating famines in the colonial world. The two of Britain's colonies that suffered the most were Ireland and India. The 1845-52 Great Irish Famine is considered a 'watershed in the modern history of Ireland'1 which killed more than one million people and contributed to the rise of anticolonial Irish nationalism. India, on the other hand, experienced numerous famines in the nineteenth century, culminating in the 1943-44 Great Bengal famine, which had a death toll of three to five million people. This famine was also vital in catalyzing anticolonial politics and art. Through a study of the literary works of these famines, I will show in this essay that colonialism, imperialism and famine/food crisis are historically linked. While existing scholarship of these famines has pointed to this interconnection, there has been little comparative analysis of literary or cultural production from these two contexts. Focussing on two novels - Liam O'Flaherty's Famine (1937) and Bhabani Bhattacharya's So Many Hungers! (1947) - I will demonstrate that there is a strong anticolonial aesthetic in these novels shaped by world-systemic/world-ecological dynamics which is comparable and yet deeply heterogeneous. This heterogeneity is shaped by the temporal distance of the works from their famines as well as by the cultural atmosphere within which they were written. I posit that a comparative study of the literary works of these famines can yield significant insights into two main factors: that the famines are political-historical and 'world-ecological' in origin and that the literary form of 'famine novels' is often used as a medium of investigation into the socio-historical. 


\section{Origins of the Famines: Food Crises in the Capitalist World-System}

Historians of food crisis and famine have informed us that the frequency of these famines in the eighteenth and nineteenth centuries was related to the European capitalist world-system. Immanuel Wallerstein (1989) argues that, with the rise of industrial revolution, the 'core' European countries such as Britain, Germany, Holland, and France had begun to incorporate 'peripheral' territories such as India or Indonesia into an interstate system by weakening these territories' manufacturing industries and domestic and overseas trade and forcing them to produce cash crops such as cotton, silk, indigo and opium. ${ }^{2}$ The historical-economic processes of empire-building and geopolitical competition in the interstate system, which together drove modernisation programmes in the periphery, integrated the nineteenth century colonial world into a single and uneven capitalist world-system. Drawing upon this theory, Jason W. Moore further argues that "socio-ecological factors" arising from the "crisis of feudalism" including soil erosion from excessive grazing, agronomic choice, monoculture, and others led to the "epochal reorganization of the world-ecology". ${ }^{3}$ Capitalist world-system is built upon the radical transformation of world-ecological conditions influencing food production and circulation in the peripheries. As Mike Davis (2001) has shown, peripheries such as Indian, Chinese, and Mexican agrarian conditions under imperialism often gave way to deep crisis moments, which the imperialist countries were not equipped to control. These instances gradually led to devastating famines and epidemics. ${ }^{4}$ During the Indian colonial period, the British started to systematically 'underdevelop' India through deindustrialisation and the commercialisation of agriculture from the nineteenth century onward in order to turn the flourishing world market of cotton into a raw material for export to Britain. The consequences were seen in a number of disasters in the late nineteenth century. As Sumit Sarkar notes in Modern India (1983), 'The colonial structure, as a whole [...] constituted a "built-in-depressor" for India's agrarian economy. The most obvious indication of this lay in 
the series of disastrous famines, in the 1870 s and again in the late 1890 s, the latter wave coinciding with the ravages of plague - while twenty years later influenza managed to kill off millions' 5

Deindustrialisation and imperialism supplemented by the Great Depression and the First World War created a huge socioeconomic crisis in the first quarter and half of twentieth century India. Economist B. M Bhatia, speaking of the 1943-44 Bengal famine, observes that there had been a considerable decline in employment and per capita income since the early years of the twentieth century, which was followed by high inflation in the post-First World War period. Between 1938 and 1943, there were crop failures, 'together with dislocation of normal channels of distribution of supplies (due to the Second World War) and a tendency on the part of the consumers, producers, and traders to hoard the supplies', which resulted in an unprecedented rise in prices and decrease in marketable surplus. The colonial administration was unprepared for this catastrophic conjunction and took no action to control prices, to combat corruption among private traders and government trading agents, or to provide quick relief measures. ${ }^{6}$ In Poverty and Famines (1981), Amartya Sen also raises many of these issues including the "vigorous speculations and panic hoardings $[\ldots]$ encouraged by administrative chaos', the 'uneven expansion in incomes and purchasing powers', and the decline of demand in crafts, utility or luxury goods (which had actively produced an underclass of artisans, fisher-folk, agricultural labourers), that created a sharp discrepancy between the actual production of food-grains and their market release, making it impossible for the poor and landless labourers to purchase rice and other essential commodities. Sen termed it the failure of 'entitlement' or the loss of the right to buy. ${ }^{7}$ These political and economic conditions prepared the ground for the famine and the subsequent food crisis in the post-famine period. 
The situation was not dissimilar in the Irish case. Although the famine was produced by a case of potato blight (a fungal attack on potatoes known as phytophthora infestans), the historical dependency of the Irish people on potatoes however had a clear politico-economic reason. Cormac Ó Gráda writes that potatoes were cheap to produce and had the nutritional value of corn at one-third of its cost. Because the population was forced to depend heavily on the crop, "Bad harvests three years in succession thus posed an unprecedented challenge for relief agencies, and arguably made disaster inevitable". ${ }^{8}$ Ó Gráda also notes that the vast amount of food that was exported to England even during the heyday of the famine exacerbated the condition. As Christine Kinealy finds out, essential commodities like peas, beans, fish, honey, etc. had left Ireland during the famine, even from the worst faminestricken areas such as Dingle, Kilrush, Limerick, Sligo and others. While relief committees such as the British Relief Association, Central Relief Committee, and others were set up, it was impossible for them to handle the magnitude of the event, and, Kinealy adds, later, all responsibilities were given to the soup kitchens. The substitute used for potatoes were lacking in nutritional values and resulted in widespread disease and a high mortality rate. She also notes that during this period, i.e. the 'Black '47', Irish landlords began to evict tenants who could not pay rent. ${ }^{9}$ Colm Tóibín shows in his book, The Irish Famine that the infamous Gregory Clause in 1847 declared that any family "holding more than a quarter of an acre could not be granted relief, either in or out of the workhouse, until they gave up their land". ${ }^{10}$ Indeed, as he further shows, Charles Trevelyan, Assistant Secretary to the Treasury, used the famine to expropriate as much land as possible from the poor. ${ }^{11}$ For Tóibín, the famine both consolidated the ruling classes and perversely strengthened anti-colonial nationalism. As we may note here, the Irish famine was never a direct result of the potato blight. The conditions of a long-term food crisis were historically, politically, and socio-economically prepared in 
the nineteenth century. The Bengal and Irish famines, thus, occurred a century apart from each other, yet bear a striking resemblance in the systemic causes for their origin.

\section{Food Crisis and Literary Form: Anticolonial Aesthetics of Famines}

While historians of famines have mostly examined administrative documents, they have often neglected the fictional and nonfictional registers which offer different dimensions of "truthvalue' regarding the famine. Both the Irish and Bengal famines resulted in a huge body of literary and artistic works. ${ }^{12}$ However, critical studies on them have been deeply inadequate. In Terry Eagleton's famous plaint in Heathcliff and the Great Hunger, "Where is the famine in the literature of the Revival? Where is it in Joyce? ...If the famine stirred some to angry rhetoric, it would seem to have traumatized others to muteness", such inadequacy appears woefully evident. ${ }^{13}$ Recently, there have been some excellent critical works on the literary writings of these famines. ${ }^{14}$ These works have been energized by the literary and cultural theories of disasters which, through a careful study of content, form, and style, have shown how literary and cultural works have offered powerful insights into the world-historical and world-ecological constructions of the famines. ${ }^{15}$ For instance, literary critic Rob Nixon in Slow Violence and the Environmentalism of the Poor (2011) points out that there are two kinds of disasters: malnutrition, famine, toxic drifts, or epidemics are 'slow' or 'attritional' disasters, while earthquakes, cyclones, or floods which occur instantaneously are 'spectacular' disasters. He defines attritional disasters as those 'that overspill clear boundaries in time and space (and) are marked above all by displacement - temporal, geographical, rhetorical and above all technological displacements'. ${ }^{16}$ In order to accommodate the nature of suffering over time and space, literary narratives of attritional catastrophes undergo a significant stretch of their generic and stylistic codes and remodel the literary form (which Nixon shows through an astute study of literary works by Arundhati Roy, Wangari Mathaai, 
Mahasweta Devi, and others). It is important to note that temporal frameworks of disaster (fast, slow, etc.) have influenced literary stylistics. As we will see below, the novels written close and distant from their famines will have their differential shaping of literary forms. However, time is not the only determining factor in the shaping of literary form. Space is also important. Upamanyu Pablo Mukherjee notes in his study on famine, fevers, and other epidemics in Victorian India (2013) that the tropics, understood by the British imperialists as the ideological zone of disaster, compelled significant modifications within the existing genres of imperial travel writing, short stories, and the historical novel. He writes, "“disaster environment" demanded disaster styles of writing'. ${ }^{17}$ In 'Towards a Postcolonial Disaster Studies', Anthony Carrigan has argued for a decolonized disaster studies where the epistemological and cultural practices of catastrophe-based texts, especially from the Global South, would be read politically through their links with the histories of colonialism, imperialism, and current forms of global capitalism. ${ }^{18}$ In another essay, Mike Niblett, drawing upon Moore's concept of world-ecology, tells us that in a long durée framework of world-history, ecological revolutions result in disruptive world-literary aesthetics in the peripheries: "for literary production from those areas subject to imperialist intrusion and forcible integration into the world-system, there will be a structural tendency towards not just registering a particular ecological regime, but also marking in explicit fashion...the disjunctions and ruptures, the breaks and rifts, engendered by ecological revolutions". ${ }^{19}$ The production of world literature is intimately tied with the production of world-history and world-ecology under the capitalist world-system.

As I argued above, the Irish and Bengal famines are world-capitalist and worldecological in origin. The literary works that they have given birth to have registered in their content, imagery, and form the imprints - violence, disruption, and aggression - of this origin. Following Niblett, the works are world-literary in character. However unlike Niblett, 
for whom the world-literary aesthetic is irrealist in form, I have found that Liam O'Flaherty and Bhabani Bhattacharya have extensively used realism in their famine novels. I have written elsewhere in detail about the realist impulse in the literary works of the 1943 Bengal famine. ${ }^{20}$ In this essay, I will show that the realism used by these authors is deeply anticolonial and heterogeneous in character. They have used different aesthetic modes, styles, and techniques which have made the realist use capacious and expansive in nature. While Bhattacharya has combined political analysis and journalistic-melodramatic modes, O'Flaherty has employed a slow, ironic, and evocative use of realism. These modes/uses are influenced by the temporality of their works (the political dynamics in their nations) as well as the cultural matrix in which they were written. This differential use of realism, I will suggest, is fundamental to aesthetic registration of world-historical catastrophes. I will begin in a non-chronological order with the Bengal famine and Bhabani Bhattacharya's novel which will allow me to demonstrate more efficiently the aesthetic differences in a novel published immediately after the famine and one that comes out in the long aftermath, as was O’Flaherty's novel.

\section{Bhabani Bhattacharya's So Many Hungers!}

During his doctoral education in London, Bhabani Bhattacharya (1906-1988) was influenced by Marxism and anti-imperialism and read political literary works. ${ }^{21} \mathrm{He}$ came back to Calcutta to work as a journalist and soon decided to write a romantic novel (Music for Mohini). But he could not proceed with the project, due to the Bengal famine. As he tells in an interview, 'The emotional stirrings I felt (more than two million men, women and children died of slow starvation amid a man-made scarcity) were a sheer compulsion to creativity. The result was the novel So Many Hungers!'.22 So Many Hungers! begins on the inauspicious day that the Second World war is declared. Its narration features multiple passages of didactic 
exposition with an expert tone that conveys an anti-colonial analysis of the causality of the food crisis, where the protagonist and main characters reason and ruminate like academics, discussing and exposing the historical conditions responsible for the famine. ${ }^{23}$ These expositions are permeated by Bhattacharya's knowledge of social history and sympathy for Marxism and anti-colonialism. Rahoul, a young scientist who has returned from Cambridge to work in Calcutta University, and Devata, his grandfather, a Gandhian, who attends to the welfare of peasants in a village called Baruni, are representative characters through whom the historical context of the famine is vocalized in the novel. When Rahoul visits Devata and they discuss nationalist struggle and redistribution of land, Devata briefly refers to the history of the Permanent Settlement: 'And he spoke of the background of Bengal's rural life - of how long ago, at the beginning of the nineteenth century, a servant of the British Trading Company made a "permanent settlement" with the landlords of Bengal, fixing for all time their annual payment to the Treasury'. ${ }^{24}$ Devata is aware of the colonial history and can see through the changes in current agrarian policy or the post-war crisis in land revenues and agriculture. This passage is infused with Bhattacharya's academic knowledge of the sociopolitical and economic history of Bengal. Devata deploys terms like value of land, agreement between landlord and cultivator, hierarchy of overlords, cash crop, and profit: 'The peasantry was not in their eyes a living mass; it was like a tract of coalfield out of which you hewed coal for profit and more profit, heedless of its exhaustion'. ${ }^{25}$

The technical vocabulary of political economy underlines the Marxist analysis at work. Marx wrote in Capital I that human labour under the capitalist system turns into a commodity and human endeavour into a mechanical thing - a process which the Caribbean anti-colonial intellectual Aimé Césaire called the 'thing-ification of life'. ${ }^{26}$ Through Devata's analysis, Bhattacharya suggests that colonialism and capitalism are deeply connected, and that in order to resist this system of abstraction and commodification and to regain human 
agency, the anti-colonial campaigns must mobilize the peasantry, boycotting Western products and using native resources (reminding us of Gandhi's call for civil disobedience and for the peasantry to unite in the struggle). The novel describes reification as the central experience of life under imperialism. As Samarendra suffers nightmares over the crashing of the Stock Exchange in Calcutta, the third person narrator sardonically declares, 'The fate of India would anyhow be decided at a conference table, and the Crown's brightest possession would change hands with the ease of a cheque passing from account to account'. ${ }^{27}$ The country is not imagined as comprised of its people or environment, but rather reduced to a piece of paper whose fate is decided at conference tables. The reference to 'the Crown's brightest possession' points to both Britain's imperialist history in India and Bhattacharya's critique of how colonies are treated as mere sites of resources for material wealth, possessions of imperialist powers to be looted, plundered, and passed on to others for further exploitation.

The newly dominant form of resource-related exploitation, Bhattacharya suggests, is the speculative mode of capitalism where resources and profit-making are based not on the availability of materials (food grains) but on the possibility - on the speculations and predictions - of such availability, and the fictitious capital to be generated by betting on risk and futures. Samarendra, who invested all his money and his wife's jewellery on speculation during the war, loses everything as Britain suffers an initial setback in WW2 (losing in Europe and East Asia): 'His large profits had been wiped clean as though they were a mere figure on the plate'; but in just a few days' time, as the British army begins to win crucial battles, his luck is restored and his riches come back doubled in profit. ${ }^{28}$ Bhattacharya portrays this mode of finance as ascendant during this period and a key factor in the famine. In Stages of Capital (2009), historian Ritu Birla argues that gambling and speculative financial practices were gradually transmuted into laws governing the market economy in late 
nineteenth-century Britain and India, antecedents to the intense speculation instituted in Calcutta during World War II. ${ }^{29}$ In the novel, Samarendra, elated with the outbreak of the War, asks Rahoul, '[s]teel will rise steeply, so will gold-which to choose? ${ }^{30}$ He knows that war is 'the most enriching industry', 'a God-sent opportunity', and that the shares market will be booming with speculation on demand and supply. For him, one needs to liquidate everything and invest it in the right speculative venture. In an innovative social realist prose reminiscent of John Steinbeck in The Grapes of Wrath, Bhattacharya records the onrush of people buying and selling war materials:

Gold rush in Clive Street. A motley crowd surging by the Stock Exchange [...] Pulses pounding. The blood beating in the ears. The crowd with cash in the banks, cash to play with [...] Buy munitions of war - things that make guns, shells [...] No rubber shares in the market? A telegram to Singapore does the trick. Send fast telegrams to Singapore. Shape up Singapore [...] What have you to buy with? Open your passbooks. Empty your accounts. Take a loan from friends. Mortgage your house. Sell, sell your gold, the gold on the body of your wife. ${ }^{31}$

This is a remarkable picture of the rise of wartime stock markets: the sheer madness of the profit economy, the pounding pulses, the rash speculations, and the liquidation of material property. Note the passage's staccato rhythm that imitates the speed of the key element of the share market - information. The passage directs our attention to how the stock economy creates its own market, especially in the example of rubber shares where the unnecessary material can be sold on the basis of rumours or communications, reminding of Karl Polanyi's notion of the self-regulating nature of capital and its production of fictitious commodities (how capital makes land, labour, and money into fictions and how these fictions shape human need). ${ }^{32}$ Bhattacharya's exuberant prose manages to convey the hurried frenzy of the city's middle class to hoard resources and acquire black mark materials that will be needed for war. 
Samarendra's investments into an unknown future is, thus, a structural part of the colonial mode of finance capitalism.

After he doubles his money on the stock market, Samarendra decides to open a rice hoarding company, Cheap Rice Ltd. As his remarks on price hikes in specific materials suggest, he is conversant with the economics of war-time booms and predicts that the colonial government will require huge quantities of rice to feed the vast number of British Indian soldiers, and that demand for all the essential commodities - rice, sugar, oil, and steel - will spike. He is so persuaded by his conjectures that he decides to give up his career as a barrister and invest all his energies in building a hoarding business. As the narrator discloses, the fantasy of speculative profit, no matter the social or environmental costs, has an irresistible attraction: 'Samarendra had no other thought that spring and summer save rice: no other interest, no other dream. He and his colleagues worked feverishly building up the business' 33

The didactic mode of historical and political analysis which the novel uses to elaborate its critique of colonial finance capitalism is juxtaposed with an incisive depiction of famine suffering whose aesthetics invoke melodrama and have an ethnographic impulse, shaping the complex realist aesthetics of the disaster text. This aesthetic shift allowed Bhattacharya to capture through literature the pathos and tragedy of the everyday violence of the famine - what Margaret Kelleher in The Feminization of Famine calls literature's power of 'quasi-intuitiveness' to express the 'inexpressible'. ${ }^{34}$ There are several episodes in the novel which are journalistic in nature and which reflect upon the brutal violence during the famine. Consider two images here. At an early stage of the famine in the village Baruni, a woman is shown to dig up a trench and bury a child alive. As Kajoli's mother intervenes, she cries and says, "“Poor godling, so hurt with hunger! Look, my breasts have no milk" - lifting the tatters that half covered her bosom - "he has no throat to cry. If he sleeps a little! Where 
is sleep? He's hurt all the time with hunger. In his cool earth bed he can close his eyes, sleep." "35 She tries to bury the child because living with a baby under such physical oppression while her fisherman husband is jailed for participation in the national liberation movement is impossible. In another episode, when the villagers decide to emigrate to Calcutta, Kajoli comes across the scene where 'a woman lay stretched by the tree-trunk, groaning while a jackal crouched and ate her body'. ${ }^{36}$ Set one after another and appearing like snapshots, these images remind us of the juxtaposition technique in John Steinbeck's The Grapes of Wrath or the strategy of 'recognition' in Bijan Bhattacharya's famine play Nabanna (New Harvest; 1944). ${ }^{37}$ These writers used these innovative techniques within their realist writing to register the contradictory social formations of wealth and poverty, the classbased nature of so-called 'natural' disasters, and to push urban middle-class readers to confront their own silence or complicity with systemic dynamics. Bhattacharya's rendering converts popular images from widely circulating newspapers into prose $\mathrm{e}^{38}$ in order to connect to the urban public, while deploying a melodramatic tone to evoke both pathos and rage. This melodramatic tone is further enforced by affective idiom such as the constant use of Bengali terms like 'Ma-Ma-go-Ma', 'Ahaare,' etc. which epitomize the orphan-like conditions of Bengal's rural population, evoking a motherly empathy for the victims as they ask for a mouthful of rice. As Bhattacharya himself noted, a novelist born in times of a huge social crisis cannot avoid the everyday scenes of horror neither can he or she avoid the documentation of such horror for raising sympathy and awareness. ${ }^{39}$ Observation, criticism, and sympathy thus become integral elements of realist representation of disaster.

The novel's aesthetic admixture of didacticism conveying a sharply political analysis with this more melodramatic style, however, attracted wide criticism by literary critics who viewed it as lacking in structural and stylistic consistency and sophistication. C. Paul Varughese, for instance, wrote that 'An artist, who turns recent events into fiction, cannot 
easily succeed; for the unconscious mind requires much time to perform its wonder of transmuting incidents into art' ${ }^{40}$ What critics at the time seemed to miss in their conventional understandings of so-called 'art' is that the literary representation of catastrophes or disasters might demand certain immediate or long-term changes and mutations within existing forms and aesthetics. The question should not be whether the novel appears as a perfectly structured or homogenously stylistic work of art, but rather what levels of rupture in cognition the novelist has endured in order to address the huge cataclysm and trauma as a witness or a contemporary, and the pressures that these thus placed on form. From such a perspective, the very 'incoherence' or mixture of realist aesthetics and styles could be themselves considered a literary innovation that itself bears witness to the experientiality of rupture or crisis. Writing immediately after the famine, Bhattacharya intended his novel to play the role of both a historical document bearing witness and a literary medium that conveys the subjective experience of collective tragedy. Furthermore, through the predominant use of this anticolonial analytical-melodramatic realist form, he reminds us that Indian independence was preceded by a dire moment of socio-ecological crisis, and that to challenge and tackle the legacies of this crisis, a visionary politics of humanistic ideals would be needed.

\section{Liam O'Flaherty's Famine}

Liam O'Flaherty, mainly known for his post-revolutionary Irish novels, Insurrection and The Informer, and his short stories, has written an intergenerational family epic in Famine (1937) spanning three generations of the Kilmartin family. Although Famine could easily be considered one of O'Flaherty's most significant texts, it has been critically neglected, despite the thematic content on the famine. ${ }^{41}$ This novel is comparable to So Many Hungers! in many aspects of form, political intent, and thematic content. Like Bhattacharya's novel, Famine was written in post-colonial Ireland, not long after independence, thus revisiting the history 
of the famine with a strong anticolonial perspective. Famine's narrative similarly begins several years before the height of the Irish famine, in the early 1840s, in order to showcase how colonial and imperialist politico-economic factors both paved the way for and accelerated famine conditions. Like Bhattacharya, O'Flaherty also employs a realist form marked by political commentary and didacticism, but which is also significantly different in its use of aesthetic modes.

In the early chapters of the novel (Chapter VI), when the full effects of the potato blight are not yet known, we see the Kilmartin family and relatives talking about the historical conditions in Ireland and their past experiences. Barney Gleeson, Mary Gleeson's father (Mary being married to Martin Kilmartin, the oldest surviving son of Brian Kilmartin, the patriarch), talks about how the declining production of potato, the main subsistence crop for the Irish peasantry, is actually a 'curse on the people and not on the land': 'The land of Ireland is holy and lovely and rich, but the tyrants have taken the rich land from the people and thrown them to live on the western rocks. It's on the bog and moor now that the people of Ireland are living and the bogs breed disease. ${ }^{42}$ The tyrants here are the British and AngloIrish capitalists who have taken over the most fertile land, displacing the poor Catholic peasantry onto boggy land with poor soil, epitomized by the topos of the Black Valley in the novel. Barney's rhetoric deploys a strong anti-colonial nationalist tone, while imagining the Irish environment as bountiful, rich, and generous. As the dialogue proceeds, a wanderer, Timothy, interjects that he has heard rumours that most of the garden crops and potatoes have been declared rotten and people have already died in thousands. The historical accuracy or potential anachronism of this exchange is perhaps at question, but what is significant is the way in which the novel deploys communal discussion and the exchange of debate and rumours to evoke the oral culture and social tensions within unlettered rural societies. Gleeson reminds the community that it was a hunger-like condition eighteen years ago which 
made him migrate from Sligo to Galway, where the novel is fictionally based: 'There was nothing else for it but death from hunger. From place to place we went with the loom on the cart with the children. Many a time we were that weak from hunger that I wanted to sell the loom, but I held on to it all the same' ${ }^{43}$ These oral memories suggest that there is already some anxiety and panic among the rural society - where the trauma of hunger is still fresh in thought and imagination - that there may be another event of hunger.

A central social tension among villagers arises from the contrast between literate and oral understandings of the political drivers underlying the famine. In several episodes, members of the literate society from the professional or ecclesiastical classes read aloud newspaper columns delineating political decisions on Ireland and engage in heated debates. This technique allows O'Flaherty to make a cogent analysis of the class relations underlying different experiences and comprehensions of rural famine conditions, and to include didactic exposition constructing his anticolonial analysis of the famine's causality. In Chapter XVI, for instance, Father Roche reads out to his fellows, Dr Hynes and Father Geelan, the news that England will not contribute anything to Ireland's current suffering for lack of potato production other than offering charity. This makes Father Roche fume with anger:

England takes five million pounds from us every year in rent alone. ... She takes three million quarters of grain every year. She takes one million herd of cattle, sheep, and swine. And now when the poor Irish people, who supply her with this wealth, year after year, have lost potato crop on which she forces them to live, she talks of charity. We want justice. Justice! We want our own. ${ }^{44}$

Recalling Christine Kenealy's later historical findings, Roche's palpable anxiety and anger express critique of the characteristic extractive dynamics of imperialism - depleting resources and subsistence possibilities and making the colonized dependent on the empire's economy. The description of Ireland as reduced to a butchery and granary may also recall Devata and 
Rahul's comments in Bhattacharya's novel about how imperialism turns a country into a commodified resource, simplifying its economic for the purposes of extraction. As Father Geelan remarks, 'I'm not, then...out of my mind atall, father John, but it's the people's leaders that are out of their minds, for letting the people's food go out of the country and then begging for some of it. Ha! Ha! It's the most foolish thing I ever heard. There isn't enough food in England to feed the English. So Ireland is kept as a granary and a butchery next door. Isn't that their policy?'. ${ }^{45}$ This comment strikes at the root of the problem here. Imperialism is an abstract economic system following systemic, abstract laws. In an imperialist economy, colonies function as resource hubs irrespective of their particular social conditions or crises. What Father Roche's comments and our discussions suggest is that the world-historical condition of imperialism give birth to the world-ecological condition of hunger and famine in colonies. If for Bhattacharya, it is the advanced speculative form of colonial capitalism and war in the mid-twentieth century that was responsible for the Bengal famine, for O'Flaherty it appears to be the mid-nineteenth century European drive of world-imperialism (the mother engine for advanced capitalist exploitation in the colonies) unevenly combined with an old feudal subsistence-based farming that exacerbated the socioeconomic conditions and prepared the grounds for the Irish famine.

While this homiletic aspect of the novel is mostly communicated by various characters (primary as well as secondary), sometimes even the narrator indulges in analysis. Consider this introductory passage from Chapter XLII:

When government is an expression of the people's will, a menace to any section of the community rouses the authorities to protective action. Under a tyranny, the only active forces are those of coercion. Unless the interests of the ruling class are threatened, authority remains indifferent. We have seen how the feudal government acted with brutal force when the interests of the landowner were threatened, even to 
the extent of plundering the poor people's property. Now it remains to be seen what the same government did when those poor lost, by the act of God, all that was left to them by the police and Mr Chadwick - the potato crop which they had sown. ${ }^{46}$

I will focus on two main aesthetic aspects of the commentary above. The first one is narratorial participation. Throughout the narrative, O'Flaherty's narrator fabricates scenarios where characters explicitly discuss the historical conditions that led to the famine and describe its impact on the affected rural population. As these dialogues unfold, the narrator remains mostly inobtrusive, describing the scene only occasionally, so that the reader's attention remains focused on the tight-neat structure of the novel. But there are also occasions like the one above where O'Flaherty's narrator intervenes with direct commentary. Here the narration's function is to historicize the condition. Note the way the imperatives of governance are theorized, suggesting the tyrannical nature of colonialism, and implying a Marxist-Leninist understanding of history as the history of ruling classes and of the ruling consciousness. Lenin, and later Mao, spoke about how ruling classes react with desperation and tyranny when their interests are threatened, and sought to evoke the possibilities of overthrowing them.

While the political intimation is clear in the commentary, this work does not operate solely at the level of polemic, but rather historicizes as well as fictionalizes the conditions of famine as an experiment in the depiction of affects and subjectivities of communities during periods of intense dispossession and crisis. Thus, a second crucial aspect of the commentary is the way the author uses the technique of anticipation in the climactic wording -- "Now it remains to be seen". What it tells us is that the narrator already knows what happened and is telling us a tale with a beginning, middle, and ending, even if the characters involved cannot be conscious of this narrative progression. The narration implies a teleological reading of history, progressively revealing the courses and events which led to a climactic crisis. This 
trope is not used abruptly. Indeed, throughout the narrative, the narrator deploys an anticipatory language of threatened or obscured futurity, as in the following instance: 'For the very poor are unable to see far into the future. If they can make provision for their immediate wants, they are not greatly troubled by a remote disaster, whose shadow is only beginning to assume shape on the horizon. ${ }^{47}$ This remark has a practical basis as the poor have few resources but immediate mouths to feed, a situation of exigency which roots them in present necessities and seldom allows them to ponder long-term futurity. But it is not also entirely correct as the novel itself has shown how the rural society was concerned and engaged in discussions of fear and panic about a possible famine in the near future. Nevertheless, what predominates is the narrator's faith in the readers' interest in heeding his tale and insistence on bearing witness to a historically conditioned disaster from the retrospective vantage of a future where its causes can better be understood than in the period of its occurrence. The climactic event - the unfolding crisis of the famine - may already be familiar to many readers, given the predominance of the famine in Irish cultural imagination and discourse. But they may not know what world-historical conditions have led to the famine and how the marginalized, tyrannized Irish rural folk have responded to them. This political motive requires a narrative technique where storytelling in current time is supplemented with retrospective historical commentary and with an anticipation of how the current conditions have shaped the fatal future. This role of a knowledgeable and assuming narrator has been possible because O'Flaherty writes this novel almost a century after the famine. Not only does he have a repository of historical data, there is also a strong presence of different narrative forms which have emerged historically from the famine - memoir, diary, poetry, theatre, novel, etc. He has the advantage of knowing the historical and aesthetic responses, finding out what has been lacking in them, and rewriting the historical with a specific political purpose. Such aesthetic use reminds us of Lukács' reading of classical realist writing 
(especially in Tolstoy) where the narrator combines conflicting political formations, fragmenting perspectives of individuals, and transparent narratorial knowledge of history and society to construct a social totality - what Perry Anderson following Fredric Jameson calls a 'totalising retrospect' ${ }^{48}$ O'Flaherty adds to it an evocative and restrained use of imagery of famine violence (as we will see below) and an epic form drawing upon a multi-generational narrative, thereby constructing another case of a disaster-based realist framework, reminiscent of Knut Hamsun's Hunger (1890).

Interestingly, this technique of anticipation or restrained imagery is almost nonexistent in Bhattacharya. Nowhere do we find the author telling us what will happen next. There is also a lack of the use of irony in the novel. Bhattacharya's work is mostly presentist in nature. This could partly be explained by their different temporal distance from the historical crises they are depicting. Because of the turbulent political and social conditions in Bengal in the 1940s, when the famine was closely followed by a peasant insurgency (the Tebhaga Andolon where farmers rose in arms against the jotedars (landlords) and mahajans (moneylenders) asking for two-thirds of the crops), it was never clear whether the famine conditions had permanently exited Bengali society and thought. For lack of available historical/sociological scholarship on the famine, Bhattacharya's novel seemed to play the role of a social and historical document. For O'Flaherty, as I pointed out, because Irish famine literature (both in its historical and literary sense) had a long heritage, he could focus on what was not said and needed to be told. This is why analysis appears strongly in both the novels because their writers, influenced by Marxism and anticolonialism, were interested in revealing the conditions that have manufactured famine and food crisis in colonies. But the temporal gap makes up for a different aesthetic use in the novels. This gap is also the reason why the two novels end on two different notes: while O'Flaherty's novel ends with the tragic end of the old patriarch Brian Kilmartin anticipating the horrors of the famine about to grasp 
Galway, or Ireland, Bhattacharya's novel has a utopian positive ending where the main protagonists Kajali and Rahul are seen to participate in nationalist movements to drive away British colonialism and capitalism. As I noted, Bhattacharya publishing the novel on the auspicious occasion of India's independence had the foreknowledge of liberation and thus could shape the structure in such a way that it looked like the famine had resulted in anticolonial nationalism and independence (which it did to a large extent). But for O'Flaherty, aware of the historical course - the post-disaster and postcolonial conditions of Ireland - as well as disillusioned with the failures of independence (and the limits of bourgeois nationalism, as opposed to anti-capitalist liberation, the horrors of the civil war etc.), a utopian end would have appeared to be naïve and unrealistic.

The temporal aspect is conjoined by a cultural matrix which enriches the differential aesthetic in the novels otherwise sharing the same world-imperialist history. Readers have already noted the journalistic-melodramatic dimension in Bhattacharya's novel. In O'Flaherty's novel, however, such melodrama is missing. As Paul A. Doyle notes, 'To the credit of his art, O'Flaherty's narrative approach - direct, documentary, matter-of-fact manages to convey the degradation and horror without either sentimentality or a note of falseness. Such a subject as the famine could easily be melodramatically overpainted and lack authenticity'. ${ }^{49}$ This is, as Doyle notes, a radical development from the early melodramatic language of his writings. One reason for this development is definitely the lack of faminerelated journalistic sensationalism during O'Flaherty's time because of the long temporal gap. The other reason is that O'Flaherty, unlike Bhattacharya, does not have the social imperative to use his literature as a tool for evidence or a social document. The political dynamics on a national scale are different for these writers. Unlike Bhattacharya, the hindsight allows O'Flaherty to ponder whether imperial power is firmly consigned to Irish history. Like the structure of his novel, slow, composed, and steady, O'Flaherty's imagery of suffering appears 
thoughtful, restrained and embodied. ${ }^{50}$ Consider a couple of images here: 'In her [Sally's] eyes was that dreadful famine look; the scared stare of an animal'. ${ }^{51}$ Later, Thomsy, Martin's brother-in-law describes a herd of migrating, disease-stricken, starved people: 'I got tidings of a body of men and I met several bodies of men, but they were all bodies of men wandering with hunger and not men on their keeping at all' ${ }^{52}$ While in Bhattacharya's novel humans and nonhuman animals (dogs and vultures) are explicitly depicted as at war with each other, in O'Flaherty's 420-odd page text there are only rumours about the gruesomeness of famine violence. More emphasis is given to an affective understanding of panic and fear, constructed by imagistic comparisons (the animal metaphor in Sally's look). Unlike in Bhattacharya, where suffering is descriptive in nature and used for the specific purpose to evoke rage and agency and to remind us not to let such a situation happen again in the uncertain and traumatic beginning of postcolonial India, for O'Flaherty imagistic (metaphorical/comparative) depiction of suffering in order to evoke pathos was never a primary agenda. O'Flaherty shows how imperialism and colonialism deteriorate an ablebodied human and turn him/her into a maimed, dependent one. Recall the evocative, minimalist imagery: Sally being compared with a wounded and scared animal who has lost confidence in herself about whether she should be able to procure food for herself. In Thomsy's description, the famine bodies appear as an abstract dehumanized collective, lacking in human values. These depictions serve O'Flaherty's main point that imperialism depletes colonized bodies and dehumanizes mankind, leaving a deep scar on human culture and interaction, and that postcolonial Ireland will have to deal with this situation, howsoever painful it is. 


\section{Conclusion:}

In this chapter, I have showed that the famines in Bengal and Ireland, although a century apart from each other, have originary links with the world-historical conditions of empire and colonialism. The novels of Bhabani Bhattacharya and Liam O'Flaherty have registered these conditions in their use of content and form. They have used a realist framework comprising the features of documentation, political analysis, depiction of suffering and pain, and narratorial intervention with suggestions regarding the famines' long-term impact on postcolonial life, culture and society. At the same time, because of the historical and geographical differences of the famines as well as the different cases of temporality and cultural matrix that have shaped these works, the realist framework is increasingly improvised and modulated. While Bhabani Bhattacharya combines a melodramaticjournalistic mode with analytical thrust in order to make his novel into a social and historical document in the immediate aftermath of the famine, O'Flaherty, writing much later from the Irish famine, has used a classical realist framework marked by the use of restrained and evocative imagery, strong sense of irony, and a slow narrative structure - thereby both of them turning disaster-based realism into a case of differential aesthetics. This essay, to conclude, has attempted to explore through close literary-comparative readings of worldfamine texts that it is not possible to write about famines and food crisis in colonies without writing about empire, and, potentially, vice versa.

\section{NOTES}

${ }^{1}$ Frank Neal, Black '47: Britain and the Famine Irish (Basingstoke: Macmillan, 1998), p.4.

${ }^{2}$ Immanuel Wallerstein, The Modern World-System III (San Diego, Cal: Academic Press, 1989), pp.123-29. 
${ }^{3}$ Jason W. Moore, “The Modern World-System” as Environmental History? Ecology and the Rise of Capitalism', Theory and Society 32.3 (2003), 307-77 (p.309).

${ }^{4}$ Mike Davis, Late Victorian Holocausts: El Niño and the Making of the Third World (London: Verso, 2001), pp.7-13.

${ }^{5}$ Sumit Sarkar, Modern India, 1885-1947 (London: Macmillan, 1989), p.36.

${ }^{6}$ B. M. Bhatia, Famines in India: A Study in Some Aspects of the Economic History of India with Special Reference to Food Problem, 1860-1990 (Delhi: Konark Publishers, 1991), p.323, pp. 333-339.

7 Amartya Sen, Poverty and Famines: An Essay on Entitlement and Deprivation (Oxford: Clarendon Press, 1981), 67-70 (p.68), 76-78 (p.76).

${ }^{8}$ Cormac Ó Gráda, The Great Irish Famine (Basingstoke: Macmillan, 1989), p.11.

${ }^{9}$ Christine Kinealy, A Death-Dealing Hunger: The Great Hunger in Ireland (Chicago: Pluto Press, 1997), pp.92-94.

${ }^{10}$ Colm Tóibín, The Irish Famine (London: Profile Books, 1999), p.10.

${ }^{11}$ Tóibín, p.40.

${ }^{12}$ For a list of the huge body of literary and artistic works based on the Irish famine, see Marguérite Corporaal, Writing of the Irish Famine (Oxford: Oxford University Press, 2014); for Bengal famine, see Srimanjari. "War, Famine, and the Popular Perception in Bengali Literature, 1939-1945" in Issues in Modern History, ed. by Biswamay Pati (Delhi: Popular Prakashan, 2000), pp.258-90.

${ }^{13}$ Terry Eagleton, Heathcliff and the Great Hunger: Studies in Irish Culture (London: Verso, 1995), p.13.

${ }^{14}$ While there have been major critical works on the literature of the Irish famine, those of the 1943 Bengal famine have been widely neglected. 
15 These discussions began with the anthropological and sociological interventions into disaster studies from the mid-90s onward. For an introduction, see Catastrophe and Culture: The Anthropology of Disaster, ed. by Susanna M. Hoffmann and Anthony Oliver-Smith (Santa Fe: School of American Research Press, 2002).

${ }^{16}$ Rob Nixon, Slow Violence and the Environmentalism of the Poor (Cambridge, MA: Harvard University Press, 2013), p.7.

${ }^{17}$ Upamanyu Pablo Mukherjee, Natural Disasters and Victorian Empire: Famines, Fevers and Literary Cultures of South Asia (Basingstoke: Palgrave, 2013), p.24.

${ }^{18}$ Anthony Carrigan, 'Towards A Postcolonial Disaster Studies', in Global Ecologies and the Environmental Humanities: Postcolonial Approaches, ed. by Elizabeth DeLoughrey, Jill Didur, and Anthony Carrigan (London: Routledge, 2015), pp.117-39.

${ }^{19}$ Mike Niblett, 'World-Economy, World-Ecology, World-Literature', Green Letters 16.1 (2012), 15-30 (p.20)

${ }^{20}$ See 'The Question of Literary Form: Realism in Poetry and Theatre of the 1943 Bengal Famine' in The Aesthetics and Politics of Global Hunger., ed. by Manisha Basu and Anastasia Ulanowicz (New York: Palgrave, 2018), pp.59-86.

${ }^{21}$ See Dorothy B. Shimer, Bhabani Bhattacharya (Boston: Twayne, 1975), p.12. It should also be noted that he began writing at a time when anti-colonialist Marxism was a dominant agenda in Indian (progressive) literature.

${ }^{22}$ Bhabani Bhattacharya, 'Interview with Bhabani Bhattacharya' Mahfil: Journal of South Asian Literature 5.1/2 (1968-1969), 43-48 (p.43). After this, he wrote another novel on the famine, He Who Rides a Tiger (1954).

${ }^{23}$ For a reading of how the novel, owing to Bhattacharya's expertise in academic and journalistic writings, draws its analytical style of discourse-making from the historical and 
social sciences, see my essay, 'Colonial Governance, Disaster, and the Social in Bhabani Bhattacharya's Novels of the 1943 Bengal Famine', ARIEL: A Review of International English Literature 47.4 (2016), 45-70.

${ }^{24}$ Bhabani Bhattacharya, So Many Hungers! (Bombay: Jaico Pub., 1964), p.19.

${ }^{25}$ Bhattacharya, Hungers, p.19.

${ }^{26}$ Karl Marx, Capital: A Critique of Political Economy Vol I, trans. by Samuel Moore and Edward Aveling (London: Lawrence and Wishart, 1970), p.27; Aimé Césaire, Discourse on Colonialism, trans. by Joan Pinkham (New York: Monthly Review Press, 1972), p.6.

${ }^{27}$ Bhattacharya, Hungers, p.29.

${ }^{28}$ Bhattacharya, Hungers, pp.34-35.

${ }^{29}$ Ritu Birla, Stages of Capital: Law, Culture, and Market Governance in Late Colonial India (Durham: Duke University Press, 2011), p.143.

${ }^{30}$ Bhattacharya, Hungers, p.6.

${ }^{31}$ Bhattacharya, Hungers, pp.15-16.

${ }^{32}$ Karl Polanyi, The Great Transformation: The Political and Economic Origins of Our Time (Boston: Beacon, 2001), p.72.

${ }^{33}$ Bhattacharya, Hungers, p.39.

${ }^{34}$ Margaret Kelleher, The Feminization of Famine (Cork: Cork University Press, 1997), pp.34.

${ }^{35}$ Bhattacharya, Hungers, p.126.

${ }^{36}$ Bhattacharya, Hungers, p.145.

${ }^{37}$ See Nandi Bhatia, Acts of Authority, Acts of Resistance: Theatre and Politics in Colonial and Post-colonial India (Ann Arbour: University of Michigan Press, 2004), p.87. 
${ }^{38}$ As a journalist, Bhattacharya was well aware of the coverage of famine violence in such newspapers as The Statesman, The Hindusthan Standard, etc. For a note, see Kali Charan Ghosh, Famines in Bengal (Calcutta: Indian Associated Pub., 1944), pp.85-95.

${ }^{39}$ In his interview with Sudhakar Joshi, Bhattacharya stated, 'I hold that a novel must have a social purpose. It must place before the reader something from a society's point of view. Art is not necessarily for art's sake. Purposeless art and literature which is much in vogue does not appear to me a sound judgement'. Qtd. in K. R. Chandrasekharan, Bhabani Bhattacharya, p. 3.

40 Varughese qtd in Chandrasekharan, Bhabani Bhattacharya (New Delhi: ArnoldHeinemann, 1974), p.9.

${ }^{41}$ Neither Chris Morash nor Melissa Fegan, both of whom have written authoritatively on the literature of the Irish famine, consider the novel worthy of sustained critical attention. Fegan recognizes the 'consummate' craftmanship of the novel but finds it comparable only to a 'morality play'. Fegan, Literature and the Irish Famine, 1845-1919 (Oxford: Clarendon Press, 2003), p.249. See also Christopher Morash, Writing the Irish Famine (Oxford: Clarendon Press, 1995).

${ }^{42}$ Liam O’Flaherty, Famine (Dublin: Wolfhound Press, 2002), p.50.

${ }^{43}$ O'Flaherty, Famine, p.52.

${ }^{44}$ O’Flaherty, Famine, p.113.

${ }^{45}$ O’Flaherty, Famine, p.119.

${ }^{46}$ O’Flaherty, Famine, p.311.

${ }^{47}$ O'Flaherty, Famine, p.56. Indeed, there are moments when the narrator seems like an old kindred spirit like figure. For instance: ‘Her (Patch Hernon's) kind was common enough in those days, a relic of old pagan times, when under Druidic law medicine had reached a high degree of perfection among us', p.138. 
48 Georges Lukács, 'Tolstoy and the Development of Russian Realism', in Studies in European Realism: A Sociological Survey of the Writings of Balzac, Stendhal, Zola, Tolstoy, Gorki and Others, trans. by Edith Bone (London: Merlin Press, 1972), pp. 126-206; Perry Anderson, 'From Progress to Catastrophe' London Review of Books, 33.15 (2011), 24-28 (p.24).

${ }^{49}$ Paul A Doyle, Liam O'Flaherty (New York: Twayne, 1974), p.99.

${ }^{50}$ Whether this style has to do with contemporary rise of Irish modernism or rather is a challenge to that is something to think about here.

${ }^{51}$ O'Flaherty, Famine, p.326

${ }^{52}$ O'Flaherty, Famine, p.368. 